\title{
Metropolitan Governance and Metropolitan Cities in Italy: Outdated Solutions For Processes of Urban Regionalisation?
}

\author{
Valeria Fedeli ${ }^{1}$
}

Received: 26 November 2015 / Accepted: 29 August 2016 / Published online: 20 September 2016

(c) Springer-Verlag Berlin Heidelberg 2016

\begin{abstract}
A form of metropolitan government in Italy was originally introduced in 1990. After 25 years, the approval of Law 56/2014 has opened a new season of experimentation, full of expectations but at the same time not exempt from critique. The paper presents and discusses the elements of innovation and path-dependency that have shaped the current normative framework, explaining in particular the climate under which the new law was adopted. The author critically focuses on three main problematic aspects of the law that institutes the new città metropolitana, i. e. the definition of boundaries, the nature of the new institution, and its competences and tools for action, considering their ability to deal with the challenges related to the processes of regional urbanisation affecting contemporary Italy.
\end{abstract}

Keywords Metropolitan governance $\cdot$ Italy · Citta metropolitana $\cdot$ Metropolitan reform $\cdot$ Planning

\section{Metropolitane Governance und città metropolitana in Italien: überkommene Lösungen für Prozesse der Regionalisierung der Stadt?}

Zusammenfassung Eine Ausprägung metropolitaner Regierung wurde in Italien erstmals in 1990 eingeführt. Nach 25 Jahren hat die Verabschiedung des Gesetzes 56/2014 eine neue Ära des Experimentierens eröffnet, eine Zeit hoher Erwartungen, aber nicht frei von Kritik. Der Beitrag diskutiert Elemente der Innovation und Pfadabhängigkeit, die den aktuellen normativen Rahmen gestaltet haben. Das

Valeria Fedeli, $\mathrm{PhD}$, Associate professor valeria.fedeli@polimi.it

1 Dipartimento di Architettura e Studi Urbani, Politecnico di Milano, Via Bonardi 3, 20133 Milano, Italy
Klima, in dem das Gesetz verabschiedet wurde, ist besonderer Aufmerksamkeit gewidmet. Die Autorin befasst sich kritisch mit drei problematischen Aspekten des Gesetzes, das die neue città metropolitana einführt: die Festlegung von Grenzen, das Wesen sowie die Kompetenzen und Handlungsmittel dieser neuen Institution. Zudem wird betrachtet, inwiefern das Gesetz imstande ist, mit den gegenwärtigen Herausforderungen der Prozesse regionaler Urbanisierung in Italien umzugehen.

Schlüsselwörter Metropolitane Governance · Italien · Città metropolitana $\cdot$ Stadtregionale Reform · Planung

\section{Introduction}

Almost 25 years after the introduction of a form of metropolitan government in Italy in $1990(\mathrm{~L} 142 / 90)^{1}$, the approval of Law 56/2014 should represent the final and

\footnotetext{
${ }^{1}$ Law 142, issued in 1990, introducing the compulsory institution of 'metropolitan areas' in Italy for the very first time has never been implemented. The institution of metropolitan areas was rendered voluntary by Law 436/1993. At the end of the nineties, with Law 265/1999, municipalities became responsible for promoting the new institution, provided by a new governmental power. More recently, in 2011, the constitutional reform recognised metropolitan areas as being on the same level as other local bodies, namely the regions, provinces and municipalities. A further law issued in 2009 tried to define the process of institutionalisation of metropolitan areas, based on the proposal of the core city or the province, in order to reduce further obstacles to their implementation. All in all, the whole story is characterised by the main cities' weak political interest in the implementation of the law, the conflict between different municipalities and the main city, and the opposition of provincial and regional government to the constitution of a new powerful territorial level. This institutional fragmentation and misalignment led to the failure of all the different legislative initiatives for almost 25 years and there remain evident obstacles today and during the current new period.
} 
definite step in the implementation of this new institutional level (see footnote 1) in a number of important urban contexts, such as Turin, Milan, Venice, Genoa, Bologna, Florence, Naples, Bari, Reggio Calabria and Rome, the capital (which will be awarded a specific status). ${ }^{2} 18$ million people are currently living in these areas, more than the $30 \%$ of the total Italian population (IFEL 2015). Actually, while the process of implementing the new law is still ongoing, a series of questions can be raised regarding its approach to the problems of government/governance in large and complex urban areas. The efficacy of the solutions provided by the law and the way in which local contexts actually interpret these solutions are completely open to debate. This paper will reconstruct the main critiques of the new institutional form, trying to highlight the elements of innovation and path-dependency that characterise the recent process of institution of the metropolitan tier in Italy. In order to do so, some background is provided, explaining the climate under which the new law was conceived and adopted. Reference is made to some of the law's original limits related to unsolved institutional issues, as well as to the specificity of the moment, particularly related to path-dependency. The author then focuses on three main problematic aspects of the new form of metropolitan government, based in particular on available accounts related to the current state of the art of the implementation process, i. e. the definition of boundaries, the nature of the new institution, and its competences and tools for action (Cittalia, 2013; Vandelli/Vitali 2014; INU 2015; De Luca/Moccia 2015; Tubertini 2015b; Vandelli 2015; Urban@it 2016). Elements of (necessary) innovation will be highlighted in terms of inputs related to the current phase of socio-spatial change, which is producing forms of regional urbanisation that seem to increment rather than reduce the persisting distance between the "de facto" city and the "de iure" city (Calafati 2014: 109), a feature that remains characteristic of the Italian case.

\section{Background: The Heavy Legacy of the Past and the Urgent Problems of the Present}

In order to argue about its limits and potentialities, its pathdependency and innovative character, the new metropolitan institution introduced by Law 56/2014 needs to be discussed and understood in terms of both its general historical background and the specific moment in which it was approved (Vandelli/Vitali 2014). The process of relaunching

\footnotetext{
2 In addition to the cities listed above, Trieste, Palermo, Catania, Messina and Cagliari, located in Autonomous Regions with special status, will also have the opportunity to become metropolitan cities, if the respective Regional Assemblies decide in favour.
}

metropolitan cities was started by the Head of Government, President Mario Monti, in July 2012 as part of the national Spending Review Law in the most serious phase of Italy's economic and political crisis. ${ }^{3}$ The Monti Government can be viewed as one of the strongest expressions of the crisis that the national political parties were going through in the new millennium. Mario Monti, an esteemed economist and professor, president of one of the most prestigious economic universities in Italy, was asked by the President of the Republic Giorgio Napolitano to form and run a government made up of technicians, with the objective of saving Italy from complete state bankruptcy, against the background of one of the deepest political crises after the nineties. In this context, Monti's intervention aimed at reducing public expenditure in Italy in face of the crisis of state resources. As part of a decree that was basically dedicated to the revision of public expenditure and approved on August 2012, article 18 introduced the institution of metropolitan cities, due to be implemented on 1 January 2014, as an accompanying measure to the abolition of the provincial tier all over Italy. On the one hand, it was, in fact, necessary for the government to use operative decrees to implement the Fiscal Federalism Act, which in 2009 had introduced the città metropolitana; on the other hand, the elimination of the provincial tier was seen as a way to reduce public expenditure, in particular in terms of the costs of politics. Provinces, in fact, were considered as a non-relevant institutional level that produced unnecessary expenses at national level. The implementation of metropolitan cities and the cancellation of the provinces were first postponed for one year by an amendment to the Stability Law of 2013. Then, in February 2013, it was suspended by a declaration of non-constitutionality. In this respect the legislative act was a sort of technical disposition with limited rationality instead of a real opportunity to apply the never implemented reform law of the 1990s (Law 142, 1990) and produce a real governance innovation. There are no strong references to a new interpretation of Italy's urban condition to back the law, nor any focused reflection related to a possible new urban question generated by it. Despite introducing a new scale of government, the law did not in fact refer directly to the necessity of addressing and solving the typical Italian paradox $^{4}$ (CSS 2011) according to which small towns and

\footnotetext{
3 The Monti Government was the $61^{\text {st }}$ government of the Italian Republic, the second and last of the XVI legislature. Started on the 16 November 2011, nominated by the President of the Republic Giorgio Napolitano after the crisis of the Silvio Berlusconi Government, it ended on 21 December 2012 when a new government, led by Enrico Letta, was appointed (based on a large coalition of political parties after the impasse generated by the results of the political elections in February 2013).

4 According to the White Paper edited by the Consiglio Italiano per le Scienze Sociali (CSS 2011). The White paper was a very first attempt
} 
large cities have the same kind of administrative organisation and powers. The limits and potentialities of the first formulation of the law in 2012 had actually already been highlighted in the document 'Metodi e Contenuti sulle Priorità in tema di Agenda Urbana' (Methods and contents on the priorities of the urban agenda), presented by Fabrizio Barca, the Minister for Territorial Cohesion at the time and a technician rather than a classic politician (Barca 2012; CIPU 2013). The document raised the question of the efficacy of the metropolitan model adopted by the law, in terms of addressing not only the problems of new urban forms in Italy but also the challenges related to the new EU programming period. Nevertheless, as we will see, this kind of consideration followed only in a second phase, in the debate raised by a more recent formulation of the law, during the current government led by President Matteo Renzi. ${ }^{5}$

In addition to this general context, since its approval the law issued by the Monti Government has been consistently opposed by the provinces (the second tier of local government in Italy instituted in 1990), which have appealed to the Constitutional Court against their own abolition. As a result, the law has suffered from a declaration of nonconstitutionality, because the abolishment of the provinces was effected by ordinary law rather than by constitutional law. For this reason, not only was its implementation very slow but the complicated technical process of abolishing the provinces to create metropolitan governments has become the central issue at stake in the institutional arena, rather than the revolutionary potentialities of the newly born metropolitan governments. On the one hand, the complicated process of outplacing provincial employees has occupied newspaper reports. On the other hand, the political and symbolic investment in the metropolitan cities was quite limited both at national and local levels. As a result, the metropolitan cities started to be regarded as successors to the previous provinces, rather than new institutions. The side effect of this was that they inherited a number of problematic issues from the provinces they were to replace, such as critical budgetary conditions, a fragile political role and maturity, competition with the regions and, last but not least, the interpretation of the province as a tier for coordination among sovereign municipalities, rather than as a real autonomous tier of government with specific competences (Bordignon/Ferri 2015; Tubertini 2015b). Provinces had remained a weak level of power ever since their establishment, with very limited resources, and their limited auton-

by the academic world to produce a new public debate on a new policy agenda for cities in Italy.

5 The current government is led by President Matteo Renzi; it is the second government of the XVII legislature and it started on 22 February 2014, after the demission of the Letta Government, due to a rather complicated crisis inside the main political party supporting his government (Partito Democratico). omy from both municipalities and regions left them with a rather weak political role and interest. This situation has been worsened by the limited transfer of competences from the regions, which in recent decades have been protagonists of a neo-centralising process. While the state has been hollowed out and promoted decentralisation, regions have played a role involving the centralisation of competences, refusing real devolution at the local level while collecting functions decentralised by the state. As a result, provinces have not really developed a true role or autonomy in the general organisation of the local state and have lacked any real capacity of action. The legacy of this weak limited efficacy and legitimacy is one of the toughest burdens that the recently instituted metropolitan governments have still to deal with.

After the general halt caused by the declaration of nonconstitutionality, the President Renzi Government decided to continue support for the initiative and re-approved the law with some major changes, thus overcoming the constitutionality problems. In fact, during 2015 the rationale and rhetoric of the law also underwent some changes, becoming oriented to a more general idea of promoting the reform of public administration in Italy as a strategic task of the new government, led by the youngest president in Italian history. This opened a new phase with the objective of both dealing with the economic crisis more fairly and introducing long-awaited institutional reforms. The government of the new president, with Minister Del Rio, pushed for a further step in the Monti law's implementation. This was part of a general process of public administration redesign, which includes the recently approved parliamentary reform - currently based on a two-chamber system - and which will see the complete reform of the Senate. ${ }^{6}$ According to the new law, 56/2014, the compulsory institution of the ten metropolitan cities by 1 January 2015 is to be complemented by the transformation of the provinces into a sort of second-tier government, in those contexts where they are not replaced by metropolitan cities (Tubertini 2015a; Vandelli 2015). At the same time, the law encouraged intermunicipal cooperation, simplifying procedures for the institution of unified municipalities and providing economic support for the merging of municipalities. Finally, the law introduced the possibility for metropolitan cities to introduce 'homogeneous zones', which are devices for coordination

\footnotetext{
${ }^{6}$ According to the reform (the so-called DDL Boschi), which has been voted on by parliament but should be approved through a referendum in October 2016, the Senate becomes a smaller chamber, whose members will no longer be directly elected but representatives of municipalities and regions nominated by the President of the Republic. One of the most interesting elements of the reform is that it will definitely change the Italian perfect bicameral system: laws in fact will be approved by the Chamber, while the Senate will have the possibility to vote on laws, but this will not be compulsory as it has been so far.
} 
among municipalities, possibly operatively supporting the management of metropolitan cities. What is more, and actually leading to the first real implementation of the new institution, the law made it compulsory to start the process of constitution in the contexts affected by the law after its approval. In addition, the relationship with the abolition of the provinces has been weakened, since this part of the reform process should involve a separate act. These have been probably the most innovative facts in the process, even if they do not necessarily guarantee the real success of this institutional initiative.

Actually, as discussed below, even the new law is not exempt from contradictions and limits, if both the general and the local perspectives are considered. It was in fact the result of a large parliamentary debate during which different stakeholders tried to introduce a more legitimate and efficient model of metropolitan government, as well as being influenced by negotiations supported by different perspectives and expectations. In our view, it therefore presents three basic problems, which are actually typical of the field of metropolitan government and are linked to the complexity of dealing with the territory-sovereignty-citizenship nexus in large urban regions. The issues are the definition of the boundaries of the new metropolitan government, the nature of the institution (elected or non-elected assembly), and its scope, competences and autonomy. The following sections will present arguments related to these limits, drawing on the available reports of its implementation recently produced by the national scientific community (Cittalia 2013; INU 2015; De Luca/Moccia 2015; Tubertini 2015b; Vandelli 2015; Urban@it 2016). From this basis, the paper goes on to warn of the real impact of the new institution in terms of improving the efficacy and legitimacy of governmental frameworks in complex urban regions.

\section{An Unsolved Metropolitan Question: The Main Problematic Aspects of the Law}

A first critical element of the new law is related to the boundaries and territorial articulation of the new institution. The indications provided by the law are quite disappointing both for theorists and for decision-makers, as one can see from both the academic debate (INU 2015; De Luca/Moccia 2015; Urban@it 2016, among others) and local and national political reports. ${ }^{7}$ The new città metropolitana will replace the provinces in most important metropolitan areas and, in terms of territorial domain, will be basically institutionalised within the boundaries of the previous provinces, inheriting both staff and functions. Other munic-

\footnotetext{
7 See in particular http://www.anci.it/index.cfm?layout=dettaglio\& IdDett=54662 (29.06.2016) and ANCI (2016).
}

ipalities will be able to join the newly instituted metropoli$\tan \operatorname{city}^{8}$, but the law has not been able to provide a real innovative answer to the general debate on the disconnection between the 'città de iure' and the 'città de facto' (Calafati 2014: 109). Regional laws recently approved all over Italy are expected to address this issue, which has been the subject of discussion in the disciplinary field for a long time, as well as in political and institutional debates (CIPU 2013). To date, at a general level, adoption of the former provincial boundaries reflects the implementation of quite a traditional logic. The new città metropolitana as such seems able to represent neither the complexity of functional urban areas nor the metropolitan areas as reformulated by OECD (2012). Thus, at this first stage, it seems unable to take advantage of local experience and debates, which during recent years have clearly shown the new urban scale and forms that the urban is assuming, forms and a scale that deserve new governance and government solutions (Balducci/ Curci/Fedeli 2016).

Looking in fact at the implementation of the law, we can clearly identify the contradictory effects of this simplification at the local level. On the one hand, there is the case of Turin while, on the other, there is Milan (INU 2015; De Luca/Moccia 2015; Urban@it 2016). In the case of Turin, the new metropolitan city inherited the former provincial boundaries and covers a very large and heterogeneous territory, which includes mountainous regions and plains, with quite different degrees of integration and relationality. Although the relationship of the city of Turin with its mountains has been theorised by notable geographers (e.g. Dematteis 2012) and explored operationally with the winter Olympics of 2006, the metropolitan character of this interaction is quite distant from expectations (see Caruso/Saccomani 2016). Faced with this territory, even the new strategic plan selects, for example, ${ }^{9}$ a more limited space in order to identify an area characterised by consistent metropolitan relationships (Castellani/Prat 2015). In the case of Milan, the former provincial boundaries, partly due to a previous division between the province of Milan and that of Monza and Brianza, do not reflect the complexity of Milan's urban region, which shows evidence of a postmetropolitan nature (see Soja 2011), or, in other words,

\footnotetext{
${ }^{8}$ Regional laws were expected to define the modalities of the redefinition of the boundary of the metropolitan cities. All the 15 ordinary regions have approved regional laws on the reorganisation of provincial functions and the related reorganisation of institutional territorial organisation (see a complete report on http://www.upinet. it/4692/istituzioni_e_riforme/lattuazione_della_legge_56_in_ambit_ regionale/ (29.06.2016)).

9 See below on strategic planning competences assigned to metropolitan cities.
} 
of urban regionalisation (Balducci/Curci/Fedeli 2016). ${ }^{10} \mathrm{In}$ both cases, the simple translation from the former provincial bodies to the current metropolitan ones has produced contradictions instead of fostering an innovative interpretation of current urban conditions.

Although the law allows for differentiated local implementation, de facto the tight link between the province and the new metropolitan city arising from the abovementioned legislative process has so far produced a linear translation of the provincial boundaries that does not consider relevant up-to-date issues. All in all, the law seems quite far from being able to address the complexity and the plurality that characterises the Italian context, with urban areas ranging from more typical metropolitan cases to urban regionalisation contexts like those characterising the so-called third Italy of the 1980s and 90s (Becattini/Bellandi/Dei Ottati et al. 2003). In the near future, it could be expected that the local implementation processes could bring forward more interesting developments, but to date everyday accounts talk about the continued debate on the distance between the real and the legal boundaries of the new institution ${ }^{11}$ (De Luca/ Moccia 2015; INU 2015).

Inevitably, this brings us to a first general question that has not been addressed consistently by the new law: are we or are we not able to design institutions that can deal with urban bundling and unbundling processes (Keil/Olds/ Addie 2012)? Is this objective feasible or should we definitely abandon the idea of finding a unique and efficient institutional solution to the new regional (or planetary, see Brenner 2014) organisation of urban contexts? The way in which boundaries are interpreted by the new law is extremely traditional: a boundary is seen as being stable, able to identify once and for all the institution's territory of action. No real mention is made of the transcalar condition that affects similar urban contexts (Brenner/Schmid 2015).

\footnotetext{
10 At the same time, in different contexts, some municipalities are applying to either enter or exit the new metropolitan city. This is possible but it must be justified with clear arguments and supported by a regional approval act, according to new regional laws to be approved for the implementation of the national one.

11 The same could be noted, just to provide another two paradigmatic examples, in the case of Città metropolitana di Roma Capitale, where the metropolitan city covers a very vast territory, the former provincial one, probably too large to identify the core urban region, and at the same time has to deal with the specific role of the national capital of the city of Rome (Cellamare 2016). In the case of Venice Città metropolitana, the città metropolitana is based on the former provincial boundaries and seems to simultaneously look for a larger scale (defined as 'metropolitan area', which includes a larger regional space with strong socio-spatial connections) able to represent the complexity of the urbanisation pattern in the Veneto context (Vettoretto/Fregolent 2016) and a more strategic definition of internal structures able to produce a policy agenda for development (see the website http://www. veneziacittametropolitana.it (29.06.2016), in particular the pages dedicated to introducing the definition of the città metropolitana).
}

This is evidently one of the most complicated issues to address. If one looks for linear solutions, any delimitation identifying the encompassing territory of the institution appears unable to cope with the transcalarity of the current urban condition. In this vein, I find it easier to imagine mobile, open and flexible boundaries, related to different kinds of objectives, i.e. management and resource provision, strategic planning, specific policy issues. Actually, considering the events of the last twenty years, one cannot but notice the complexity and density of the multiple or single policy issue networks and assemblages (Latour 2005; Sassen 2006), soft spaces (Allmendinger/Haughton/ Knieling et al. 2015) that have been generated and replaced by others year after year. This practice, if not providing the reference framework for a new governance model, should at least have been a sort of guideline for the new law and the new metropolitan cities. Rather than identifying a definitive boundary, the law should have focused more attention on devices able to generate and regenerate 'territories of (for) policies', 'territories by design', which should be based on the reciprocal, even if temporary, engagement of actors on a specific problem, but at the same time able to contribute to a general practice of cooperation and to feed a new governance model. Nothing of the sort has happened: it will be up to each metropolitan plan - locally defined and adopted - to introduce ways of addressing this challenge. Even if this flexibility is considered positive, the scarce attention given to this issue does not, I feel, support or foster the experimentation that would be required to address this governance problem responsibly and innovatively.

A second critical element, closely linked to the first, has to do with the nature of the new institution, both in terms of its relationship with the municipalities and the citizens and the relationship between the public and the private spheres. The government of the new metropolitan city will be based on three main bodies, i. e. the President, the Metropoli$\tan$ Council and the Metropolitan Conference. The first will be the institutional representative and has the executive power, together with the second, which not only will approve programmes and plans, but will also adopt the budgetary schemes and finally the budget, after a positive assessment by the metropolitan conference. This last body will have consultative power and the power to propose. Its proposals can be adopted or rejected with a qualified majority (votes representing one-third of the municipalities and half the population of the città metropolitana). According to the law, the mayor of the città metropolitana will be the mayor of the capital city and the council will be composed of the mayor and 24 councillors in the case of metropolitan cities with more than 3 million inhabitants (18 for cities with populations between 80,000 and 3 million, 14 for towns with fewer than 80,000 inhabitants). Both will be directly elected only in metropolitan cities with more than 
3 million people, if the capital city introduces forms of decentralised power within its boundaries. ${ }^{12}$ The Metropolitan Conference will be composed of the President and all the mayors of the municipalities that belong to the metropolitan city. The local plan will define voting modalities.

As one can see, and as discussed at local level, the new institution has some potential limits in terms of representation and legitimacy - it promotes a new institution that is not directly elected, unlike the former provinces. This is more than a constitutional problem and cannot be reduced to appealing to the Constitutional Court, as has been done. In fact, it becomes a real legitimacy problem for a new institution that was born with an original democratic deficit. It does not contribute to raising the citizens' interest in the new institution, in particular the citizens of the municipalities other than the central city. This is because only the citizens of the largest city, after which the new città metropolitana will be named, will really be able to vote for the new metropolitan city president who, by law, will be the mayor of the central city. This model could also affect the nature of the relationship between municipalities that are members of the metropolitan cities, reproducing an historical contraposition. The Constitutional Court (sent. 50/2015) recently decreed that an institution can be democratic even if it is indirectly elected. Nevertheless, whether urban regions do or do not deserve innovative forms of representation, able to represent the rescaling of citizenship in post-metropolitan conditions, remains a critical issue.

One example of the effects of this traditional logic can be found in the way in which the current process of negotiation of the National Operational Programme (NOP) 2014-2020 has been held (Pasqui/Briata/Laino 2016). This document, in which national strategies are defined in relation to European ones, identifies two different targets of urban authorities: the 14 metropolitan cities on the one hand and medium-sized cities and regional urban hubs on the other. Actually, the identification of the former is quite paradoxical: all the negotiated projects mainly address central/main cities and not the whole metropolitan context. Central cities, at the end of the day, remain the central actors in the process and little or no attention is given by either the Ministry or the cities to the innovative approaches required when dealing with metropolitan governance forms (Pasqui/Briata/Laino 2016).

A second kind of effect in terms of implementation is revealed by analysis of the currently adopted documents that highlights that most of the metropolitan cities studied have

\footnotetext{
12 In all cases all roles are unpaid and the metropolitan council is otherwise elected by the mayors and municipal councillors of the municipalities. They can be elected among mayors and councillors of the municipalities. Votes are calculated on the basis of a specific weighted calculation related to the demographics of municipalities.
}

chosen indirect election (Turin, Genoa, Florence, Bologna and Bari), while only Rome, Naples and Milan will adopt the direct election model after a transition phase. At the end of the day, from this perspective, the metropolitan city remains in many respects tightly linked to an institutional model based on horizontal coordination between municipalities, rather than a brand-new institution. The presence of the Metropolitan Conference, where municipalities are strongly represented, the role of the homogeneous zones (the possibility of dividing metropolitan cities into sub-areas, which could also manage decentralised functions), and the indirect election of the President seem rather to configure an institution of coordination than an innovative autonomous subject able to deal with the challenges of new metropolitan citizenship. This is not necessarily negative, but it should have probably been better conceived in order to promote a model of institution based on transcalar relationships. In this respect, some of the devices provided by the law could be better used and interpreted, e. g. the definition of the abovementioned homogeneous zones (sub-areas comprising municipalities with similar profiles, intended to play an intermediate role of coordination between the municipal level and the metropolitan level) could become an opportunity to organise stronger and more strategic roles for processes of voluntary cooperation between municipalities, able to express a more mature and responsible form of representation and dialogue based on political interaction with the metropolitan city government. At the same time, mechanisms for the direct involvement of citizens, civil society and stakeholders should have been introduced, in order to provide a new governance model. A few local plans have introduced mechanisms or forms allowing the stable involvement of socio-economic actors or the consultation of citizens, in order to develop a sense of belonging to the new institution. To date, referendums seem to be the only method permitting this kind of input and as such they have been introduced by some of the plans (Tubertini 2015a; Vandelli 2015). But the complexity of transcalar decision-making, which cross-cuts local and regional policy issues and challenges, probably deserves more complicated and innovative solutions. In this respect it can also be noted that the law, in contrast to other European contexts, has not taken seriously the opportunity to introduce the stable and permanent consultation of socio-economic actors. This fact has generated serious critical interest in some of the associations, in particular those representing economic actors, which at least at a local level have organised lobbies to obtain clearer involvement in the process, while in general supporting the new metropolitan institution as a strategic resource to manage complex urban systems. ${ }^{13}$ All in all, this introduces a second general question, related to the ne-

\footnotetext{
${ }^{13}$ In particular the local seats of Confindustria, the association of industrial entrepreneurs, have established a coordination group in order
} 
cessity to introduce a more updated idea of governance able to produce new forms of political representation.

Finally, with regard to the competences, the città metropolitana will mainly inherit the competences and roles of the former provinces, related to the coordination of the action of municipalities, but they will also be charged with new functions and their strategic role will be increased. According to the national law, they will be responsible for strategic development, the integrated management of facilities, infrastructures and communication at metropolitan level and they will manage relations with other cities and metropolitan areas in Europe. ${ }^{14}$ In particular, they will be in charge of:

- a three-year strategic plan (a clearer description is not provided), which will be the main guiding act,

- territorial planning (also fixing limits to municipal action),

- structuring coordinated systems for the management of public facilities at the metropolitan level,

- mobility and road networks,

- economic and social development promotion, together with the promotion and coordination of information, communication and digital technologies.

Regions and municipalities may provide metropolitan cities with further functions. Different regional laws have introduced specific functions at the local level. Nevertheless, the national law makes no special mention of the necessity of new tools and devices for action, i.e. special functional agencies or sub-coordination areas useful in the management of particular functions (although specific homogeneous zones can be instituted at no additional public expense). Again no specific spaces of structured interaction with local actors (economic actors, civil society, etc.) are introduced in order to deal with complex governance problems and objectives, such as the competitiveness of urban regions, their lack of liveability or increasing spatial differentiation, all of which are the focus of both the European and the national debate (Barca 2012; CIPU 2013). The law does not appear to provide specific hints, nor does it seem to grant this issue dedicated attention. It seems to leave room for local interpretation, but there is a consistent risk of reproducing a useless institution, unable to manage tasks or gain the output legitimacy that would be required in order to embed it in the traditional institutional framework. As a matter of fact, the ongoing processes of implementation of strategic planning competences provide contradictory in-

to monitor the situation. In the case of Milan, for example, Assolombarda, the local association of entrepreneurs, has promoted a number of studies to support the process and has tried to have a voice in the approval of the local plan in order to have more defined involvement in the governance of the città metropolitana (see Biondi 2016).

14 According to Paragraph 44-46 of the Law 56/2014. terpretations. Nevertheless, the intensity of activities that this has generated witnesses to the interest of local actors in new planning tools that are able to overcome the limits of statutory planning, in particular in terms of addressing complex and non-traditional governance settings and governance problems (De Luca/Moccia 2015; Urban@ it 2016). ${ }^{15}$

Actually, in the sphere of competences, much of the future success of metropolitan cities will be based on the capacity to address the complicated relationship with the regions. In fact, the failure of the provinces was basically due to the limited transfer of power and competences from the regions, which have played a re-centralisation role in recent decades, both at local and national level. This interinstitutional conflict should be avoided, but, as a matter of fact, it is not just a traditional problem of institutional relationships: considering the nature of contemporary regional urbanisation processes in many of the metropolitan cities, it is clear that the metropolitan scale is becoming more and more intertwined with the regional scale. In other words, in many cases the regional dimension overlaps with the metropolitan one. At the same time, in a context like the Italian one, the historical power of the municipalities and citizens' identification with their small or medium-sized city is so strong that the challenge of identifying a new model of competences and powers is quite hard to address. Nevertheless, recent decades have clearly shown that the practices of citizens in urban regions generate a mobile and itinerant condition of territoriality (Tarrius 2010), which would deserve a new concept of citizenship (Donzelot 2009; Merrifield 2014a; Merrifield 2014b). A new model of management of competences and power is therefore needed for a new promise of urbanity, meant as a new right to the city, at a new metropolitan scale. Who can deal with the problems of mobility in urban regions? Who can address the competitiveness issues of urban regions? Who can provide new models for public housing, based on a regional strategy and able to avoid the historical limits of decentralisation policies that generated new peripheries rather than new centralities? Who can provide citizens with a new offer of urbanity based on a multiple set of opportunities, managed on a transcalar base, generated by interaction between a local and efficient municipal system and a regional one? In other words, are we able to invent new governance tools or governance frameworks able to address the problems of urban regions? To what extent does the regional dimension require a new model of public action and a new notion of management of competences and interaction between institutional levels? Much of the problem, at the end of the day, is also currently linked to the limited economic and fiscal resources assigned to metropolitan cities (Bordignon/Ferri 2015). Available models are quite var-

\footnotetext{
15 To follow both these processes, see http://www.urbanit.it (29.06.2016).
} 
ied. The new metropolitan city could invest in a role of coordination between municipalities or support to municipalities, rather than an active and autonomous role (Tubertini 2015a). Many of these questions will be addressed by regional laws, which should implement the national one. There is the high risk - again - of the regions playing a recentralisation role. All in all, it may be concluded, the law has not been able to innovatively define competences able to introduce a new model of efficient and legitimate public action, mixing coordination and autonomy in a flexible and non-traditional way.

\section{Is the Metropolitan Model Still the Right Solution to Problems of Governance in Urban Regions? Looking for a New Notion of Citizenship and Governance in a Post- Metropolitan Condition}

The international literature and the everyday experience of citizens and decision-makers converge in highlighting how some of the characteristics historically associated with the idea of the city are undergoing a complete reconfiguration, stressing and superseding a number of the official features and attributes of 'cityness' (Brenner/Schmid 2015: 152, 162). In light of the multiplication of the 'urban', a category which can no longer be isolated in a stable and significant form (Amin/Thrift 2002), and the regionalisation of the urban (Soja 2011), the city becomes an ambiguous and difficult object to identify (Martinotti 1999). This has strong implications both for our ideas about urban governance and for models of government and understandings of citizenship (Fedeli/Perrone/Marconi et al. 2016).

According to Donzelot (2009), the idea of social citizenship is the outcome of a process of formulation and reformulation of other forms and concepts of citizenship, progressively driven by the discovery of the limits of the previous model by that part of the population excluded from it at a certain point. Civil citizenship in this sense was originally related to the general acknowledgment of the notion of the equality of all individuals with regard to justice, property rights and freedom of exchange. Political citizenship enlarged rights to freedom of thought and opinion, including all those that have the possibility of obtaining respect, and it was based on a wider notion of the sovereignty and autonomy of all individuals. Social citizenship was an answer to the material limits of political citizenship, aimed at granting all the individuals an answer to their needs. When, at the end of the nineteenth century, the social question gained a more typical urban dimension, citizenship became urban: the city, with all its problems, was on the scene and the social question became an urban question. The right to be claimed was the 'right to the city', as a promise of rights and opportunities. Is this idea of urban citizenship still able to deal with the challenges raised by the dynamics produced so far by large urban regions, which traditional administrative treatment still identifies with the concept of 'metropolis'? Is this idea of metropolis, assumed by institutional reforms in Italy, as well as in other European contexts, still relevant and able to shape a new governance model able to address the current urban question and demand for citizenship? In this conclusion, I would like to introduce a further and final argument relevant to the analysis of the current institutional reform. Not only are the idea of citizenship and the models of governance made available by the law not able to address metropolitan governance challenges. Even the metropolitan model per se is quite outdated, since this law is trying to govern something different from what the 'metropolitan model' attempts to grasp, at least as it was formulated in the last century.

The concept of post-metropolis, proposed by Edward Soja more than fifteen years ago and recently revised (Soja 2000; Soja 2011), can, with other concepts, highlight the distance between the metropolitan model and the current situation, characterised by "the emergence of a distinctive new urban form, the extensive, polynucleated, densely networked, information-intensive and increasingly globalized city region [...], a polycentric network of urban agglomerations, where relatively high densities are found throughout the urbanized region" (Soja 2011: 7). It is a context in which a "multi-scalar process of regional urbanisation" is taking place (Soja 2011: 3), inside which it is no longer possible to distinguish between urban and suburban, the first conceived as the space of heterogeneity, social interaction and conflict, the second as the space of homogeneity and poverty of resources, opportunities and density. In a similar mood, Roger Keil and Douglas Young adopt the notion of in-betweenness, proposed by Sieverts in 2003 in the context of experience in the Ruhr in post-unification Germany (Sieverts 2003: 21), and focus on a city that can no longer be defined in static terms, since it expresses a series of dynamic relationships between the urban and the globalised urban world (Young/Keil 2010). In this sense, processes of suburbanisation are seen as the outcomes of new interactions between novel rationalities: strategies of growth, practices of collective consumption, residential expansion, preservation of the environment and landscape. The 'suburban' that Keil, Wood and Young (2011) propose looking at is therefore, per se, not just the field of the rescaling of traditional social and environmental urban problems, but the heart of a new political tension, if not the best space for tension to accumulate. At the same time, it is where theoretical frameworks that have been used to describe the city in terms of urban politics, such as, for example, growth machine theory (Molotch 1976) but also urban regime theory (Stone 1993), show their difficulty in detaching from 
an idea of the city as the outcome of stabilised governance patterns.

From an even more challenging perspective Neil Brenner reminds us that the traditional definition of the 'urban' and the urban question (Brenner 2014: 15) is related to the idea of the 'city' as a specific form of settlement, characterised by dimensions, density and social diversity that clearly distinguish it from a 'non-city social world' (Brenner 2014: $15)$, located outside or beyond the urban world. Brenner's hypothesis is that a process of capitalist urbanisation is taking place, which involves the so-called non-urban realm and obliges the reframing of both theory and practices of the urban realm. Discussing Lefebvre's position, according to whom "society is completely urbanized" (Lefebvre 2014: 36), Brenner states that cities and agglomerations should not escape our attention, but should be interpreted as "sites, evolutive arenas, in which wider socio-spatial and socioecological transformation takes place" (Brenner 2014: 19). Brenner questions in particular the effects on the political and institutional dimension and on the possibility of conceptualising a new citizenship in this condition, referring to a condition of 'empowerment' of the people who live in such contexts. The persistent lack of conceptualisation of the issue of citizenship in a transcalar perspective - "offline somewhere local, online somewhere planetary" (Merrifield 2014a: 174) - is a central challenge: "Right to what city? If urbanization is planetary, if the urban - or urban society - is everywhere, is this right to the city the right to the metropolitan region, right to the whole urban agglomeration? Or does it just mean the right to a certain neighbourhood, to the city's downtown, the right to centrality? And if there are centers everywhere, just as there are multiple peripheries, does that mean the right of these peripheries to occupy, take back, the centers?" (Merrifield 2014b: 525). Merrifield draws a paradoxical conclusion here. If everywhere is urban, the question of citizenship cannot be linked to a traditional model of the city, place-based and local, and not even to a metropolis, I would add.

Regional urbanisation, post-metropolis, in-betweenness, planetary urbanisation: all in all, these new theories of the urban dimension suggest the necessity of looking at the implications of the new spatial scale of urban processes in order to reshape our understanding of the city and the way in which we design policies and institutions able to deal with the contemporary urban fabric. A recent research project dedicated to exploring the Italian situation (see Balducci/ Curci/Fedeli 2016; Urban@it 2016) has highlighted that the Italian case is characterised by the emergence of differentiated and structurally complex urban regions that present traces of regional urbanisation that would require a new governance model. Between path-dependency and innovation, Italian major urban areas are characterised by an historical condition of polycentrism which has been hybridised with processes of regional urbanisation such as those described by Edward Soja (2011). On the one hand, in fact one can recognise the persisting relevance of urbanisation patterns and the role of historical networks of cities, on the other hand one should also acknowledge the formation of large conurbations which can be read not only as forms of explosion of major large cities, but as the result of a process of complex interplay between the polycentric structure and processes of regional urbanisation as described in other European and North American contexts. With the exception of very few cases (partly Rome and Turin), this has not happened within a traditional metropolitan model as described by early twentieth century urban theory, but takes a somewhat peculiar form that deserves a sophisticated governance imaginary. As a matter of fact, this specific nature, scale and dimension of the urban in Italy requires inedited and courageous experimentation, able to give voice and expression to questions, expectations, needs and problems that have neither voice nor expression in the traditional idea of citizenship, and able to support our understanding and our policy and governance design. Who supports the demands of a commuter travelling in a large urban region? What access to public mobility is granted to people in suburban areas? What are the problems, e.g., of young people or older people in the in-between? What are the specific peculiarities of gender issues in this condition? Which is the political space of representation of the new citizens of the regional city? A braver reform would probably be needed to give voice to the 'invisible citizens' of the current urban condition, a reform that could provide new forms of social representation (and urban fabric) and re-establish and feed local democracy (Rosanvallon 2014). A critical observation of the rationale of the current reform in the field of metropolitan governance in Italy, as well as a first look at its temporary outcomes, makes clear the complexity of every act of institutional design for such an urban condition. The analysis of the current state of the art in the Italian case highlights the difficulties in reducing the shift between the "de facto" city and the "de iure" city, the elements of pathdependency that lie beneath this strong challenge, and the need for innovation that goes beyond our consolidated and codified answers to problems - that is to say, institutions.

\section{References}

Allmendinger, P.; Haughton, G.; Knieling, J.; Othengrafen, F. (eds.) (2015): Soft spaces in Europe: Re-negotiating governance, boundaries and borders. London.

Amin, A.; Thrift, N.J. (2002): Cities: Reimagining the urban. Cambridge.

ANCI - Associazione Nazionale dei Comuni Italiani (2016): La riforma metropolitana in Italia e le Questioni Aperte. Roma.

Balducci, A.; Curci, F.; Fedeli, V. (2016): Una galleria di ritratti dell'Italia post-metropolitana. In: Territorio 76, 20-22. 
Barca, F. (2012): Metodi e obiettivi per un uso efficace dei fondi comunitari 2014-2020. Roma.

Becattini, G.; Bellandi, M.; Dei Ottati, G.; Sforzi, F. (eds.) (2003). From industrial districts to local development: An itinerary of research. Cheltenham.

Biondi, V. (ed.) (2016): Milano Metropoli Possibile. Padova.

Bordignon, M.; Ferri, V. (2015): Per una nuova finanza delle città metropolitane. Roma. = Working Papers. Rivista online di Urban@it. http://www.urbanit.it/wp-content/uploads/2015/10/BP A_Bordignon-Ferri-2.pdf (29.06.2016).

Brenner, N. (2014): Urban theory without an outside. In: Brenner, N. (ed.): Implosions/Explosions: Towards a Study of Planetary Urbanization. Berlin, 14-35.

Brenner, N.; Schmid, C. (2015): Towards a new epistemology of the urban? In: City 19, 2-3, 151-182.

Calafati, A. (2014): Città e aree metropolitane in Italia. L'Aquila. = GSSI Urban Studies Working Paper 1.

Caruso, N.; Saccomani, S. (2016): Torino: verso un processo di regionalizzazione. In: Territorio 76, 28-34.

Castellani, V.; Prat, A. (2015): Prime riflessioni sulla Città metropolitana di Torino. Roma. = Working Papers. Rivista online di Urban@it. http://www.urbanit.it/wp-content/uploads/2015/09/BP_ A_Castellani.pdf (29.06.2016).

Cellamare, C. (2016): Cosa è successo a Roma. Metamorfosi dell'abitare nel territorio post-metropolitano romano. In: Territorio 76, 59-67.

CIPU - Comitato interministeriale per le politiche urbane (2013): Metodi e contenuti sulle priorità in tema di agenda urbana. Roma.

Cittalia (2013): Rapporto Cittalia 2013. Le città metropolitane. Roma. http://www.casaportale.com/public/uploads/15282-pdf1. pdf (29.06.2016).

CSS - Consiglio Nazionale delle Scienze Sociali (2011): Libro bianco sul governo delle città italiane. Roma.

De Luca, G.; Moccia, F.D. (eds.) (2015): Immagini di territori metropolitani. Roma.

Dematteis, G. (2012): La metro-montagna: una città al futuro. http:// storicamente.org/quadterr2/dematteis.pdf (29.06.2016).

Donzelot, J. (2009): Vers une citoyenneté urbaine. Paris.

Fedeli, V.; Perrone, C.; Marconi, G.; Munarin, S. (2016): Conoscenze. Le trasformazioni delle città italiane. In: Urban@it - Centro nazionale di studi per le politiche urbane (ed.): Rapporto sulle città. Metropoli attraverso la crisi. Bologna, 15-35.

IFEL - Istituto per la Finanza e l'Economia Locale (2015): Le città metropolitane nelle regioni a statuto ordinario - Scheda n. 38 . Roma. http://formazione.fondazioneifel.it/index.php/numeri-eterritori/item/1517-le-citta-metropolitane-nelle-regioni-a-statutoordinario-scheda-n-38 (29.06.2016).

INU - Istituto Nazionale di Urbanistica (2015): Rapporto dal territorio 2016. Roma. http://www.inu.it/wp-content/uploads/preview.pdf (29.06.2016)

Keil, R.; Olds, K.; Addie, J-P. (2012): Mobilizing new urban structures to increase the performance and effect of R\&D in universities and beyond. SSHRC Knowledge Synthesis Grant Leveraging Public Investments in HERD. Toronto.

Keil, R.; Wood, P.B.; Young, D. (eds.) (2011): In-Between Infrastructure: Urban Connectivity in an Age of Vulnerability. Kelowna.

Latour, B. (2005): Reassembling the social: An introduction to actornetwork-theory. Oxford.
Lefebvre, H. (2014): From the City to Urban Society. In: Brenner, N. (ed.): Implosions/Explosions: Towards a Study of Planetary Urbanization. Berlin, 36-51.

Martinotti, G. (ed.) (1999): La dimensione metropolitana. Bologna.

Merrifield, A. (2014a): The Urban Question under Planetary Urbanisation. In: Brenner, N. (ed.): Implosions/Explosions: Towards a Study of Planetary Urbanization. Berlin, 164-180.

Merrifield, A. (2014b): The Right to the City and Beyond: Notes on a Lefebvrian Reconceptualization. In: Brenner, N. (ed.): Implosions/Explosions: Towards a Study of Planetary Urbanization. Berlin, 523-533.

Molotch, H. (1976): The City as a Growth Machine: Toward a Political Economy of Place. In: American Journal of Sociology 82, 2, 309-332.

OECD - Organisation for Economic Co-Operation and Development (2012): Redefining "Urban". A New Way to Measure Metropolitan Areas. Paris.

Pasqui, G.; Briata, P.; Laino, G. (2016): Risorse. Fondi comunitari per le città metropolitane. In: Urban@it - Centro nazionale di studi per le politiche urbane (ed.): Rapporto sulle città. Metropoli attraverso la crisi. Bologna, 29-34.

Rosanvallon, P. (2014): Le parlement des invisibles. Raconteur la vie. Paris.

Sassen, S. (2006): Territory, authority, rights: From medieval to global assemblages. Princeton.

Sieverts, T. (2003): Cities without cities: an interpretation of the Zwischenstadt. London.

Soja, E. (2000): Postmetropolis. Oxford.

Soja, E. (2011): Regional Urbanization and the End of the Metropolis Era. In: Bridge, G.; Watson, S. (eds.): The New Blackwell Companion to the City. Oxford, 679-689.

Stone, C.N. (1993): Urban regimes and the capacity to govern: A Political Economy Approach. In: Journal of Urban Affairs 15, 1, $1-28$.

Tarrius, A. (2010): Territoires circulatoires et étapes urbaines des transmigrant(e)s. In: Regards croisés sur l'économie 2, 8, 63-70.

Tubertini, C. (2015a): La città metropolitana tra Regione, Comuni ed Unioni. Analisi delle relazioni istituzionali. Roma. = Working Papers. Rivista online di Urban@it. http://www.urbanit.it/wpcontent/uploads/2015/09/BP_A_Tubertini.pdf (29.06.2016).

Tubertini, C. (2015b): Le province. In: Almeida Cerreda, M.; Tubertini, C.; Costa Gonçalves, P. (eds.): La racionalización de la organización administrativa local: las experiencias española, italiana y portuguesa. Madrid, 417-456.

Urban@it - Centro nazionale di studi per le politiche urbane (ed.) (2016): Rapporto sulle città. Metropoli attraverso la crisi. Bologna.

Vandelli, L. (2015): L'innovazione del governo locale alla prova: uno sguardo comparato agli Statuti delle Città metropolitane. In: Rivista di Studi Giuridici e Politici, Número Extraordinario 1, 213-238.

Vandelli, L.; Vitali, W. (2014). Il cammino accidentato verso le città metropolitane. In: Vitali, W. (ed.): Un'agenda per le città. Nuove visioni per lo sviluppo urbano. Bologna, 75-90.

Vettoretto, L.; Fregolent, L. (2016): Il Veneto dopo la terza Italia: spazi metropolitani e postmetropolitani. In: Territorio 76, 59-68.

Young, D.; Keil, R. (2010): Reconnecting the disconnected: the politics of infrastructure in the in-between city. In: Cities 27, 2, $87-95$. 